\title{
Kebijakan Legislasi Sistem Pemidanaan Sebagai Upaya Perlindungan Hukum Terhadap Anak Di Indonesia
}

\author{
Nandang Sambas \\ Fakultas Hukum Unisba \\ J1. Rangga Gading No. 8 Tlp. 022-4264066. \\ nandangsambas@yahoo.com
}

\begin{abstract}
The regulation on the criminalization system in the positive criminal justice, as stipulated in Criminal Code and Law Number 3 of 1997 on Children Court, viewed from the formulation policy aspect, still has weaknesses and shortages. The problems of this research are: First is whether the policy on criminalization system toward children in positive justice in Indonesia is relevant to the objectives of children legal protection. Second is how the legislation of the renewal on the criminalization system that can provide the legal protention for children of Indonesia is. This research is a descriptive and prescriptive research. The research uses normative juridical approach. The result of the research concludes that, first, the formulation policy on criminalization system toward children in positive criminal justice both in Criminal Code and Law Number 3 of 1997 on Children Court, viewed from policy/criminal political aspect, is not yet relevant with the essence of the implementation of children court, namely to give legal protection and rehabilitation to delinquent children. Second, the concept of formulation system on children criminalization which can give protection to reach the children welfare, to name but a few, integrated and non-partial regulation on the criminalization system.
\end{abstract}

Key words : Formulation policy, criminalization system, children protection..

\begin{abstract}
Abstrak
Pengaturan sistem pemidanaan dalam hukum pidana positif, sebagaimana diatur dalam KUHP maupun Undang-Undang Nomor 3 Tahun 1997 tentang Pengadilan Anak, dilihat dari aspek kebijakan formulasi, masih mengalami berbagai kelemahan dan kekurangan. Permasalahan dalam penelitian ini, pertama, apakah kebijakan sistem pemidanaan terhadap anak dalam hukum positif Indonesia sesuai dengan tujuan perlindungan hukum terhadap anak? Kedua, bagaimana kebijakan legislasi pembaruan sistem pemidanaan yang dapat memberikan perlindungan hukum bagi anak di Indonesia? Penelitian ini bersifat deskriptif dan preskriptif. Penelitian ini menggunakan pendekatan yuridis normatif. Hasil penelitian menyimpulkan, pertama, kebijakan formulasi sistem pemidanaan anak dalam hukum pidana positif baik dalam KUHP maupun Undang-Undang Nomor 3 Tahun 1997 tentang Pengadilan Anak, dilihat dari aspek kebijakan/politik kriminal belum sesuai dengan hakikat dilaksanakannya peradilan anak yaitu memberikan perlindungan hukum dan rehabilitasi anak delinkuen. Kedua, konsep kebijakan formulasi sistem pemidanaan anak yang dapat memberikan perlindungan demi tercapainya kesejahteraan anak, antara lain adanya ngaturan sistem pemidanaan secara utuh dan tidak bersifat parsial.
\end{abstract}

Kata kunci : Kebijakan formulasi, sistem pemidanaan, perlindungan anak. 


\section{Pendahuluan}

Sejalan dengan kecenderungan perkembangan terhadap perlindungan HAM di dunia, telah mempengaruhi suasana reformasi yang terjadi di Indonesia. Kondisi demikian terbukti dengan dilakukannya amandemen UUD-RI 1945 dengan dicantumkannya secara tegas Bab X A tentang perlindungan HAM, termasuk di dalamnya perlindungan terhadap Anak. ${ }^{1}$

Dalam hukum pidana positif upaya perlindungan hukum terhadap anak (anak nakal/yang bermasalah dengan hukum/ABH), sebelumnya telah diatur dalam Kitab Undang-Undang Hukum Pidana (selanjutnya disebut KUHP) sebagaimana diatur dalam Pasal 45, Pasal 46 dan Pasal 47 KUHP. Namun demikian, sejalan dengan arah pembaruan hukum pidana serta didorong adanya keinginan memberikan pembinaan dan perlindungan terhadap generasi muda, maka dikeluarkan Undang-Undang No. 3 Tahun 1997 tentang Pengadilan Anak. ${ }^{2}$ Dalam konsideran menimbang bagian b UndangUndang Pengadilan Anak ditegaskan "bahwa untuk melaksanakan pembinaan dan memberikan perlindungan terhadap anak, diperlukan dukungan, baik yang menyangkut kelembagaan maupun perangkat hukum yang lebih mantap dan memadai, oleh karena itu ketentuan mengenai penyelenggaraan pengadilan bagi anak perlu dilakukan secara khusus". Dengan dikeluarkannya undang-undang tersebut, maka upaya perlindungan hukum terhadap anak telah diatur secara khusus di luar KUHP.

Secara normatif masalah pokok dalam hukum pidana meliputi tiga persoalan pertama, perbuatan apa yang sepatutnya dipidana (perbuatan yang bersifat melawan hukum/criminal act/daad); kedua, syarat apa yang seharusnya dipenuhi untuk mempertanggungjawabkan seseorang yang melakukan perbuatan itu (pertanggungjawaban pidana/criminal responsibility/dader); dan ketiga, sanksi/pidana apa yang sepatutnya dikenakan terhadap orang yang telah melakukan perbuatan itu (punishment/straf). ${ }^{3}$ Dari ketiga porsoalan pokok tersebut masalah "pidana" dan

${ }^{1}$ Pasal 28 B ayat (2) perubahan UUD 1945 menyatakan bahwa: "Setiap anak berhak atas kelangsungan hidup, tumbuh, dan berkembang serta berhak atas perlindungan dari kekerasan dan diskriminasi”.

${ }^{2}$ Dalam konsideran menimbang bagian b Undang-Undang Pengadilan Anak ditegaskan "bahwa untuk melaksanakan pembinaan dan memberikan perlindungan terhadap anak, diperlukan dukungan, baik yang menyangkut kelembagaan maupun perangkat hukum yang lebih mantap dan memadai, oleh karena itu ketentuan mengenai penyelenggaraan pengadilan bagi anak perlu dilakukan secara khusus".

${ }^{3}$ Barda Nawawi Arief, "Beberapa Aspek Pengembangan Ilmu Hukum Pidana (Menyongsong Generasi Baru Hukum Pidana Indonesia)". Pidato pengukuhan Penerimaan Jabatan Guru Besar dalam Ilmu Hukum Pada Fakultas Hukum Universitas Diponegoro, Semarang, 1994, hlm.16. Muladi, Beberapa Catatan Berkaitan Dengan RUU KUHP Baru, Makalah Seminar Nasional RUU KUHP Nasional, Universitas Internasional Batam, 2004. Herbert L. Packer, dalam bukunya "The Limit of The Criminal Sanction", menyatakan bahwa : The rationale of the criminal law rets on three concepts : offence, guilt 
pemidanaan menempati posisi sentral dalam peradilan pidana, serta membawa konsekwensi yang sangat luas baik bagi pelaku maupun masyarakat pada umumnya. Oleh karena itu dalam penegakan hukum pidana masalah pidana dan pemidanaan mengandung makna yang sangat kompleks dan mendalam baik secara yuridis, sosiologis, maupun filosofis.

Dalam perkembangannya, pendekatan retributif dalam sistem pemidanaan mulai bergeser ke arah pendekatan kemanfaatan (utilitarian approach). Dalam pendekatan kemanfaatan, hukum pidana dan sanksi pidana dianggap merupakan salah satu dari sekian sarana yang oleh masyarakat dapat digunakan untuk melindungi dirinya dari pelaku yang dapat membahayakan. Kegunaan sanksi pidana dinilai dari sudut apakah dengan mengenakan sanksi tersebut dapat diciptakan kondisi yang lebih baik. Apabila pandangan fundamentalis menitikberatkan pada ancaman terhadap perasaan moral masyarakat sebagai pembenaran penggunaan sanksi pidana, maka pandangan utilitarian selalu berpijak pada kepentingan masyarakat (public order) sebagai sarana perlindungannya. Menurut Emile Durkheim, pidana sendiri merupakan suatu pranata sosial yang dihubungkan dan selalu mencerminkan nilai serta struktur masyarakat, sehingga merupakan suatu reafirmasi simbolis atas pelanggaran terhadap "hati nurani bersama" atau collective conscience. ${ }^{4}$

Sudarto ${ }^{5}$ menyatakan bahwa, bagian terpenting suatu kitab undang-undang hukum pidana adalah stelsel pidananya. Stelsel pidana yang memuat aturan tentang jenis-jenis pidana dan juga ukuran dan pelaksanaan dari pidana-pidana itu, dapat dijadikan ukuran sampai seberapa jauh tingkat peradaban bangsa yang bersangkutan. Dari jenis ukuran dan cara pelaksanaannya itu, dapat dinilai bagaimana sikap bangsa itu melalui pembentukan undang-undangnya dan pemerintahannya terhadap warga masyarakatnya sendiri atau terhadap orang asing yang telah melakukan pelanggaran terhadap hukum pidana.

Secara filosofis dilaksanakannya peradilan anak bukan semata-mata ditujukan sebagai proses penjatuhan/pemberian sanksi, melainkan ditujukan untuk

and punishment. These three concept symbolize the three basic problem of substance in the criminal law : (1) What conduct should be designated as criminal; (2) what the terminations must be made before a persone can be found to have commited a criminal offense; (3) what should be done with persons who are found to have commited criminal offenses. The Limits of the Criminal Sanction, stanford, California, Standford University Press, 1968, hlm. 17.

${ }^{4}$ Harkristuti Harkrisnowo, Rekonstruksi Konsep Pemidanaan : Suatu Gugatan terhadap Proses Legislasi dan Pemidanaan di Indonesia, Pidato Pengukuhan Jabatan Guru Besar Tetap dalam Ilmu Hukum Pidana. Fakultas Hukum Universitas Indonesia, Depok, 2003, hlm. 2.

${ }^{5}$ Sudarto, Suatu Dilema dalam Pembaharuan Sistem Pidana Indonesia, Fakultas Hukum Universitas Diponegoro, Semarang, 1979, hlm. 5-6. 
memberikan perlindungan demi kepentingan masa depan anak. Berbeda dengan peradilan bagi orang dewasa, peradilan ditujukan untuk membuktikan kesalahan perbuatan yang telah dilakukakan serta berupaya menjatuhkan sanksi pidana sebagai imbalan sesuai dengan kesalahannya. Dari aspek model peradilan, saat ini berkembang model peradilan restorative ${ }^{6}$ yang dianggap lebih manusiawi. Model ini menggeser nilai filsafati penanganan anak dari penghukuman menuju rekonsiliasi, pembalasan menuju penyembuhan korban, pengasingan dan kekerasan menuju keperansertaan dan kekerabatan masyarakat keseluruhan, destruktif yang negatif menuju perbaikan, pemberian maaf yang sarat dengan kasih sayang. Oleh karena itu, sejalan dengan upaya pembaruan melakukan reformulasi sanksi pidana bagi anak yang dapat memberikan perlindungan serta mengedepankan prinsip memberikan yang terbaik bagi anak (the best interest of the child) merupakan suatu keharusan.

\section{Rumusan Masalah}

Atas dasar paparan tersebut di atas, yang menjadi permasalahan pokok dalam penelitian ini: pertama, apakah kebijakan sistem pemidanaan terhadap anak dalam hukum positif Indonesia sesuai dengan tujuan perlindungan hukum terhadap anak? Kedua, bagaimana kebijakan legislasi pembaruan sistem pemidanaan yang dapat memberikan perlindungan hukum bagi anak di Indonesia?

\section{Tujuan Penelitian}

Penelitian ini bertujuan untuk mengetahui: Pertama, kebijakan sistem pemidanaan terhadap anak dalam hukum positif Indonesia apakah sesuai dengan tujuan perlindungan hukum terhadap anak. Kedua, kebijakan legislasi pembaruan sistem pemidanaan yang dapat memberikan perlindungan hukum bagi anak di Indonesia.

\footnotetext{
${ }^{6}$ Menurut Andi Hamzah, Peradilan Restoratif (Restoratif Justice) secara umum ditujukan termasuk perkara berat, sebagaimana dikembangkan dalam konsep hukum Islam yang dapat diterapkan dalam perkara pembunuhan, dimana antara keluarga korban dan pelaku terjadi perdamaian dan yang melanggar hukum memberi ganti kerugian. Namun peradilan Restoratif ini sulit diterapkan di Indonesia, karena budaya orang Indonesia yang "pendendam". Begitu juga Nico Keijzer, seorang Guru Besar Hukum Pidana Belanda, tidak setuju dengan restoratif justice (bukan afdoening buiten process), karena hal itu merupakan bentuk pemaafan. (Andi Hamzah, Pembangunan Hukum Pidana Indonesia, makalah Seminar Pengaruh Globalisasi terhadap Hukum Pidana dan Kriminologi Menghadapi Kejahatan Transnasional, ASPEHUPIKI, Bandung, Maret 2008, hlm. 12.
} 


\section{Metode Penelitian}

Penelitian ini bersifat deskriptif dan preskriptif. Sifat penelitian deskriptif karena penelitian ini dilakukan untuk mencari data seteliti mungkin dan lengkap tentang karakteristik suatu keadaan atau gejala-gejala yang dapat membantu mengkaji teori lama untuk membangun teori baru mengenai sistem pemidanaan, khususnya sistem pemidanaan terhadap anak. Bersifat deskriptif bertujuan untuk membuat deskripsi, gambaran atau lukisan secara sistematis, faktual dan aktual mengenai fakta-fakta, sifat-sifat serta hubungan antar fenomena sistem pemidanaan, khususnya sistem pemidanaan anak. ${ }^{7}$

Penelitian ini menggunakan pendekatan yuridis normatif yaitu penelitian hukum yang sepenuhnya mempergunakan data sekunder. ${ }^{8}$ Penelitian hukum yang normatif menekankan pada langkah-langkah spekulatif-teoritis dan analisis normatifkualitatif. ${ }^{9}$

Pengumpulan data dilakukan dengan menggunakan teknik studi kepustakaan (Library Research) serta ditunjang dengan penelitian lapangan (Field Research) guna mendukung dan menunjang data sekunder yang telah diperoleh pada studi kepustakaan. Sebagai suatu penelitian hukum normatif, maka dilakukan metode analisis secara kualitatif melalui penerapan metode-metode penafsiran dan konstruksi hukum dengan logika hukum sebagai instrumen yang sangat penting. Atas dasar hal itu, maka analisis data yang diterapkan dalam penelitian ini juga terarah pada analisis data yang bersifat yuridis kualitatif, dengan menggunakan logika induktif abstraktif, logika yang bertolak dari "khusus ke umum".

\footnotetext{
${ }^{7}$ Menurut Whiteney, metode deskriptif adalah pencarian fakta dengan interprestasi yang tepat. Penelitian deskriptif mempelajari masalah-masalah dalam masyarakat, serta tata cara yang berlaku dalam masyarakat serta situasisituasi tertentu, termasuk tentang hubungan, kegiatan-kegiatan, sikap-sikap, pandangan-pandangan serta proses-proses yang sedang berlangsung dan pengaruh-pengaruh dari suatu fenomena. Moh. Nazir, Metode Penelitian, Ghalia Indonesia, Jakarta, 2003, hlm.5.

${ }^{8}$ Ibid.

${ }^{9}$ J. Supranto, Metode Penelitian Hukum dan Statistik, Rineka Cipta, Jakarta, 2000, hlm. 3.
} 


\section{Hasil Penelitian dan Pembahasan}

\section{Pengertian Kebijakan}

Istilah kebijakan dalam uraian ini diambil dari istilah "policy" atau "politiek", maka kebijakan hukum pidana dapat pula disebut "politik hukum pidana" atau lebih dikenal dengan "Penal policy" atau "Criminal Law Policy" atau "strafrechtspolitiek". Kebijakan hukum pidana atau politik hukum pidana dilihat dari aspek politik hukum maupun politik kriminal dapat diartikan sebagai berikut: a) usaha untuk mewujudkan peraturan-peraturan yang baik sesuai dengan keadaan dan situasi pada suatu saat. ${ }^{10}$ b) kebijakan dari negara melalui badan-badan yang berwenang untuk menetapkan peraturan-peraturan yang dikehendaki yang diperkirakan bisa digunakan untuk mengekspresikan apa yang terkandung dalam masyarakat dan untuk mencapai apa yang dicita-citakan. ${ }^{11}$

Pencegahan dan penanggulangan kejahatan dengan memanfaatkan sarana "penal" merupakan "penal policy" atau "penal law enforcement policy" yang terwujud lewat seperangkat norma-norma yang berlaku di masyarakat. Perangkat norma hukum tersebut dapat diklasifikasikan menjadi norma-norma hukum yang sedang berlaku (hukum positif/ius constitutum) dan norma-norma hukum pidana yang dicita-citakan ( ius constituendum). Terkait dengan cara bagaimana merumuskan hukum pidana yang sebaiknya atau seharusnya untuk masa yang akan datang, berarti memasuki bidang ilmu tentang kebijakan atau politik hukum pidana ("Strafrechtpolitiek/criminal-law policy/ penal-policy"). Menurut Marc Ancel, Penal Policy merupakan salah satu komponen esensial dari "Modern Criminal Science" di samping "Criminology" dan "Criminal Law". ${ }^{2}$

Di kemukakan pula bahwa "Penal policy" adalah suatu ilmu sekaligus seni yang pada akhirnya mempunyai tujuan praktis untuk memungkinkan peraturan hukum positif dirumuskan secara lebih baik dan untuk memberikan pedoman tidak hanya kepada pembuat undang-undang, tetapi juga kepada pengadilan yang menerapkan undang-undang dan juga kepada para penyelenggara atau pelaksana putusan pengadilan. ${ }^{13}$

\footnotetext{
${ }^{10}$ Sudarto, Kapita Selekta Hukum Pidana, Alumni, Bandung, 1981, hlm. 159.

${ }^{11}$ Sudarto, Hukum Pidana dan Perkembangan Masyarakat Kajian terhadap Pembaharuan Hukum Hidana, Sinar Baru, Bandung, 1983, hlm. 20.

${ }^{12}$ Marc Ancel, Social Defance, A Modern Approach to Criminal Problems, Routlarge \& Kegan Paul, London, 1965, hlm. 4-5.

${ }^{13}$ Barda Nawawi Arief, Tanpa Tahun, hlm. 1.
} 
Pada hakikatnya masalah kebijakan hukum pidana bukanlah semata-mata pekerjaan teknik perundang-undangan yang dapat dilakukan secara yuridis normatif dan sistematik dogmatik. Di samping pendekatan yuridis-normatif, kebijakan hukum pidana juga memerlukan pendekatan sosiologis, historis, dan komparatif; bahkan memerlukan pula pendekatan komprehensif dari berbagai disiplin sosial lainnya, serta pendekatan integral dengan kebijakan sosial dan pembangunan nasional pada umumnya.

Usaha dan kebijakan untuk membuat peraturan hukum yang lebih baik pada hakikatnya tidak dapat dilepaskan dari tujuan penanggulangan kejahatan. Kebijakan hukum pidana juga merupakan bagian dari politik atau kebijakan kriminal (criminal policy). Sudarto mengungkapkan bahwa kebijakan kriminal dapat diuraikan ke dalam tiga arti, yaitu : a. dalam arti sempit, adalah sebagai keseluruhan asas dan metode yang menjadi dasar dari reaksi terhadap pelanggaran hukum yang berupa pidana; b. dalam arti luas, adalah keseluruhan fungsi dari aparatur penegak hukum, termasuk di dalamnya cara kerja dari pengadilan dan polisi; c. dalam arti paling luas, adalah keseluruhan kebijakan yang dilakukan melalui perundang-undangan dan badan resmi, yang bertujuan untuk menegakan norma-norma sentral dalam masyarakat. ${ }^{14}$

Kebijakan itu sendiri diartikan sebagai suatu keputusan yang menggariskan cara yang paling efektif dan paling efisien untuk mencapai suatu tujuan yang ditetapkan secara kolektif. ${ }^{15}$ Dalam UUD 1945 telah dirumuskan secara khusus perlindungan HAM terhadap anak sebagaimana diatur dalam Pasal 28 B ayat (2) bahwa: "Setiap anak berhak atas kelangsungan hidup, tumbuh dan berkembang serta berhak atas perlindungan dari kekerasan dan diskriminasi". ${ }^{16}$

Dalam Deklarasi Hak-Hak Anak ditegaskan pula, bahwa: "Wherears the child, by reason of his physical and mental immaturity, needs special safeguards and care, including appropriate legal protection, before as well as after birth. ${ }^{17}$

Begitu pula dalam Konvensi Hak-Hak Anak 20 November 1989, ditegaskan bahwa: "Bearing in mind that, as indicated in the Declaration of the Rights of the Child, "the

\footnotetext{
${ }^{14}$ Sudarto, Kapita Selekta ..., Op.Cit., 1981. hlm. 113-114, lihat juga Hukum dan Hukum Pidana, 1981, hlm.161.

15 Sutan Zani Arbi dan Wayan Ardhana. Rencana Penelitian Kebijakan Sosial, Pustekkom Dikbud dan C.V. Radjawali, Jakarta, 1984. Dalam Barda Nawawi Arief, Kebijakan Legislatif dalam Penanggulangan Kejahatan dengan Pidana Penjara. Semarang, CV. Ananta, 1994, hlm. 63.

${ }^{16}$ Undang-Undang Dasar RI 1945, hasil amandemen kedua.

${ }^{17}$ Deklarasi PBB 20 November 1958.
} 
child, by the reason of his physical and mental immaturity, needs special safeguards and care, including appropriate legal protection, before as will as after birth"18.

Pengaturan secara khusus mengenai penanganan anak dalam sistem peradilan pidana, terutama dalam memutuskan untuk mengambil tindakan, instrumen Internasional tentang standar peradilan pidana anak, menegaskan sebagai berikut : 1. bahwa dalam penjatuhan sanksi bukan hanya memperhatikan keseimbangan berat ringannya pelanggaran yang dilakukan, tetapi pada kondisi dan kebutuhankebutuhan si anak serta kebutuhan masyarakat; 2. melakukan pembatasan dan perampasan terhadap kebebasan/ kemerdekaan anak harus dipertimbangkan seselektif mungkin, yaitu apabila anak melakukan kekerasan atau tindak pidana serius terus-menerus serta tidak ada lagi bentuk sanksi lain yang lebih tepat; 3 . mengedepankan faktor kesejahteraan bagi anak; 4. anak-anak jangan dikenakan pidana badan. ${ }^{19}$

Dalam Resolusi PBB 45/113 tentang "U.N. Rules for the Protection of Juveniles Deprived if their Liberty" antara lain dinyatakan: 1. pidana penjara harus digunakan sebagai upaya terakhir. 2. perampasan kemerdekaan anak harus ditetapkan sebagai upaya terakhir dan untuk jangka waktu minimal yang diperlukan serta dibatasi untuk kasus-kasus yang luar biasa.

Dalam Undang-Undang Nomor 39 Tahun 1999 tentang HAM ditegaskan dengan menyatakan bahwa tindakan memisahkan anak dengan orang tuanya haruslah didasarkan pada kepentingan yang terbaik bagi anak. Pasal 66 undang-undang tersebut menyatakan: "Penangkapan, penahanan, atau pidana penjara anak hanya boleh dilakukan sesuai dengan hukum yang berlaku dan hanya dapat dilaksanakan sebagai upaya terakhir".

Dalam ayat selanjutnya ditegaskan pula, bahwa: "Setiap anak yang dirampas kebebasannya berhak mendapatkan perlakuan secara manusiawi dan dengan memperhatikan kebutuhan pengembangan pribadi sesuai dengan usianya dan harus dipisahkan dari orang dewasa, kecuali demi kepentingannya" ${ }^{20}$

Mengedepankan kepentingan anak dalam kondisi apapun harus diprioritaskan, dan dalam rangka menjaga perkembangan jiwa serta kepribadiannya, seorang anak harus mendapat kebebasan dan perlindungan yang baik dari semua pihak, terutama

\footnotetext{
${ }^{18}$ Resolusi PBB Nomor. 44/25, 20 November 1989.

${ }^{19}$ Beijing Rule: Rule 17.

${ }^{20}$ Pasal 66 ayat (4) dan (5) UU No. 39 Tahun 1999 tentang HAM.
} 
dari negara dan pemerintah. Sebagaimana dinyatakan dalam Undang-Undang Perlindungan Anak, bahwa negara dan pemerintah berkewajiban dan bertanggungjawab menghormati dan menjamin hak asasi setiap anak. Negara dan pemerintah pun berkewajiban dan bertanggungjawab memberikan dukungan sarana dan prasarana dalam penyelenggaraan perlindungan anak. ${ }^{21}$

\section{Kebijakan Sistem Pemidanaan dalam Hukum Pidana Positif.}

Sistem pemidanaan (the sentencing system) merupakan aturan perundangundangan yang berhubungan dengan sanksi pidana dan pemidanaan (the statutory rules relating to penal sanctions and punishment). Dapat dilihat dari sudut fungsional yaitu keseluruhan sistem yang mengatur bagaimana hukum pidana ditegakkan secara kongkrit sehingga seseorang dijatuhi sanksi pidana. Sistem pemidanaan demikian identik dengan sistem penegakkan hukum pidana yang terdiri dari substansi hukum pidana materiiel, substansi hukum pidana formal, dan substansi hukum pelaksanaan pidana. Sistem pemidanaan fungsional diartikan pula sebagai sistem pemidanaan dalam arti luas.

Dilihat dari sudut norma-substantif, sistem pemidanaan dapat diartikan sebagai keseluruhan sistem norma hukum pidana materiil untuk penjatuhan dan pelaksanaan pidana. Sistem pemidanaan dalam arti substantif diartikan pula sebagai sistem pemidanaan dalam arti sempit. Atas dasar pengertian tersebut, maka keseluruhan peraturan perundang-undangan baik yang ada dalam KUHP, maupun di luar KUHP, pada hakikatnya merupakan satu kesatuan sistem pemidanaan sebagai aturan umum dan sebagai aturan khusus.

Sejalan dengan persoalan masalah pemidanaan, baik pidana (straf) maupun tindakan (maatregel) akan dirasakan sebagai sesuatu yang tidak mengenakan. Apalagi kalau pidana tersebut berupa pidana perampasan kemerdekaan (imprisonment), persoalan masalah keadilan akan sangat menonjol dirasakan oleh pelbagai pihak yang merasa dirugikan oleh tindak pidana.

Pada hakikatnya dengan dijatuhkan pidana, semua konflik harus selesai, keseimbangan harus kembali dan mendatangkan rasa damai bagi masyarakat. Tujuan hukum pidana dengan segala operasionalisasinya adalah semata-mata ditujukan demi melindungi masyasarakat dan memberikan rasa keadilan bagi korban, pelaku

${ }^{21}$ Pasal 21 dan 22 UU No. 23 Tahun 2002 tentang Perlindungan Anak. 
maupun masyarakat (protection of the public and the promotion of justice for victim, offender and community). ${ }^{22}$

Berbicara masalah hukum tidak akan lepas dari suatu sistem, yaitu sistem hukum yang berlaku dalam tatanan kehidupan bernegara. Dalam penegakkan keadilan, bukan hanya hakim yang dituntut menjatuhkan putusan yang adil, tetapi undang-undang itu sendiri haruslah mengandung rasa keadilan sekaligus hukum yang dapat mengubah keadaan sosial (law as a tool of social engineering).

Persoalan dengan sistem pemidanaan terhadap anak, sejalan dengan keabsahan pemikiran para ahli/pemerhati anak, diakui bahwa hakikat perbuatan menyimpang (delinkuen) yang dilakukan anak, sesungguhnya bukan atas dorongan/motivasi dari dirinya, melainkan besar dipengaruhi oleh kondisi yang ada di luar dirinya. Apa yang dilakukan anak, baik yang disengaja karena ketidaktahuannya ataupun tidak sengaja sebagai akibat akumulasi rasa frustrasi serta kekecewaan terhadap lingkungan yang banyak menekannya hanyalah tindakan yang dapat dikualifikasikan sebagai bentuk kenakalan. Dengan demikian, anak tersebut masih bisa dibimbing dan diperbaiki perilakunya. Atas dasar hal itu, kalaupun seorang anak terpaksa harus ditangani melalui lembaga peradilan, tidaklah adil dengan menjatuhkan sanksi pidana perampasan kemerdekaan (penjara) sebagaimana lazimnya perlakuan terhadap orang dewasa.

Dalam hukum positif kebijakan perlindungan terhadap anak bermasalah dengan hukum $(\mathrm{ABH})$ secara khusus dapat ditemukan baik dalam KUHP maupun dalam Undang-Undang Nomor 3 Tahun 1997. Di dalam KUHP, ketentuan yang secara khusus mengatur masalah pertanggungjawaban anak dapat ditemukan dalam Pasal 45, 46, dan 47 KUHP. Ketiga pasal tersebut di dalamnya mengatur masalah batas usia anak, tentang kewenangan hakim dalam menjatuhkan ancaman sanksi, serta lamanya pidana. Ketentuan umum yang mengatur masalah pemidanaan sebagaimana diatur dalam KUHP meliputi: a) pengaturan tentang sistem pemidanaan secara umum tersebar dalam ketentuan buku I KUHP. Ketentuan umum tentang pemidanaan yang diatur dalam KUHP selain mengatur masalah stelsel pidana, antara lain mengatur juga masalah pidana bersyarat Pasal 14 a-f, pelepasan bersyarat Pasal 15 dan 15 a-b KUHP. Tentang alasan penghapusan atau pengurangan pidana sebagaimana diatur dalam Pasal 44, 48 KUHP. Ketentuan tentang melakukan percobaan kejahatan Pasal 53 percobaan pelanggaran sebagaimana diatur dalam Paal 54 KUHP. Tindak pidana

${ }^{22}$ Muladi, Kapita Selekta Sistem Peradilan Pidana, BP. Universitas Diponegoro, Semarang, 1995, hlm.127-129. 
penyertaan diatur dalam Pasal 55, 56, 57, dan Pasal 58 KUHP, pembantuan Pasal 60 KUHP. Tindak pidana berbarengan (concursus) sebagaimana diatur dalam Pasal 63 KUHP, maupun pidana berlanjut yang diatur dalam Pasal 64 KUHP); b) ancaman sanksi yang diatur dalam Pasal 10 untuk anak dikurangi 1/3, dan pidana 15 tahun untuk ancaman pidana mati atau seumur hidup; c) dianut model pemidanaan double tract system (pidana dan tindakan).

Namun demikian, dengan pertimbangan memberikan dukungan dalam upaya pembinaan dan perlindungan terhadap anak, maka dikeluarkan Undang-Undang No. 3 Tahun 1997 tentang Pengadilan Anak. Adanya UU No. 3 Tahun 1997 tentang Pengadilan Anak diakui sebagai suatu kemajuan bila dibandingkan dengan KUHP. Hal-hal baru yang diatur dalam UU No. 3 Tahun 1997, antara lain: a. dalam hal hukum pidana materiel: 1) adanya ketentuan tentang batas usia minimum anak di bawah umur yang dapat diajukan ke pengadilan; 2) dirumuskannya pengertian kenakalan anak; 3) diaturnya jenis sanksi baik pidana maupun tindakan; 4) pengaturan tentang pidana bersyarat; 5) pengaturan tentang pelepasan bersyarat. $b$. dalam hal hukum pidana formal/ hukum acara: 1) ditentukan aparat penegak hukum yang secara khusus menangani pelaku anak;2) diatur secara khusus lembaga yang terlibat dalam penanganan anak; 3) diaturnya tata cara peradilan anak, dari mulai penangkapan sampai pelaksanaan pidana.

Apabila dikaji lebih jauh esensi UU No. 3 Tahun 1997 ternyata belum menyentuh upaya perlindungan anak secara mendasar. Hal itu dapat dilihat dari hal-hal sebagai berikut: 1. dalam hal merumuskan kualifikasi perbuatan yang dikategorikan sebagai kenakalan. Bagi seorang anak melakukan perbuatan yang dapat dijatuhi sanksi bukan hanya melakukan tindak pidana, namun segala perbuatan yang dinyatakan terlarang bagi anak baik menurut UU maupun peraturan lain. Pengaturan seperti itu jauh lebih luas bila dibandingkan dengan klasifikasi tindak pidana bagi orang dewasa; 2. walaupun dalam UU No. 3 Tahun 1997 telah ditegaskan batas usia pertanggungjawaban bagi anak nakal, namun secara normatif masih memungkinkan anak di bawah 12 tahun untuk diperiksa di pengadilan; 3. masalah pengaturan jenis sanksi, dalam UU No. 3 Tahun 1997 sudah menghapuskan pidana mati. Namun ancaman sanksi dalam UU Pengadilan Anak masih berorientasi kepada penerapan sanksi pembatasan/perampasan kemerdekaan. Hal itu tampak dengan masih dicantumkannya sanksi pidana penjara sebagai sanksi yang utama dan pertama dalam urutan stelsel pidana anak. 
Masalah lain yang sangat mendasar dalam hal sistem pemidanaan anak adalah konsekwensi adanya ketentuan yang mencabut 3 pasal dalam KUHP (Pasal 45, 46, 47). Adanya ketentuan tersebut telah menimbulkan implikasi yuridis terhadap apa yang menjadi alas hukum dalam sistem pemidanaan anak. Sebagaimana telah diungkapkan bahwa pengaturan sistem pemidanaan anak dalam KUHP bukan hanya sebagaimana diatur dalam Pasal 45, 46, dan 47 saja. Melainkan tersebar dalam ketentuan umum buku I KUHP. Bahkan ketentuan sistem pemidanaan yang diatur secara khusus dalam UU No. 3 Tahun 1997 justeru lebih memberatkan bagi anak. Antara lain dalam hal pengaturan masalah pidana bersyarat, walaupun dalam Undang-Undang Pengadilan Anak telah diatur dalam Pasal 29, namun Pasal 14 a-f KUHP secara yuridis masih tetap berlaku bagi pelaku anak. Hal itu karena Undangundang Pengadilan Anak sendiri tidak secara tegas menyatakan bahwa ketentuan yang ada dalam KUHP dinyatakan tidak berlaku. Permasalahan yang muncul adalah ketentuan mana dari kedua aturan tersebut yang akan diberlakukan terhadap anak?

Begitu juga masalah pembebasan bersyarat, walaupun pengaturan dalam Undang-Undang Pengadilan Anak ada keringanan jika dibandingkan dengan ketentuan dalam KUHP, dimana masa percobaan hanya ditetapkan selama sisa pidana yang harus dijalankannya, tanpa ditambah satu tahun sebagaimana ditentukan dalam KUHP. Namun persyaratan yang ditetapkan Undang-Undang Pengadilan Anak disamakan dengan syarat yang ditetapkan dalam KUHP. Padahal dilihat dari ancaman pidana yang dijatuhkan terhadap anak, undang-undang menegaskan dikurangi $1 / 2$ (satu perdua) untuk pidana sementara waktu, dan maksimal sepuluh tahun untuk ancaman pidana seumur hidup atau pidana mati. Atas dasar hal itu, sangatlah wajar apabila syarat pembebasan bersyaratpun tidak disamakan dengan ketentuan untuk orang dewasa sebagaimana ditentukan KUHP.

Menyangkut ketentuan mana yang akan diberlakukan, permasalahan sebagaimana ditemukan dalam pengaturan pidana bersyarat bisa juga timbul dalam hal aturan tentang "pembebasan bersyarat", dalam hal ini akan memberlakukan Pasal 15 KUHP yang juga tidak dinyatakan tidak berlaku oleh Undang-Undang Pengadilan Anak, atau ketentuan di dalam Pasal 62 Undang-Undang Pengadilan Anak yang pengaturannya ditempatkan dalam Bab VI tentang "Lembaga Pemasyarakatan Anak."

Kondisi demikian telah mempengaruhi kebijakan aplikatif serta eksekutif, sebagai wujud penegakkan hukum pidana anak dalam masyarakat. Berdasarkan 
data Dirjen Pemasyarakatan, terhadap anak nakal yang dikenakan penahanan, maupun sebagai anak didik pemasyarakatan rata-rata pertahun jumlah menunjukkan kenaikan.

\section{Kebijakan Legislasi Pembaruan Sistem Pemidanaan yang Dapat Melindungi Kepentingan Anak.}

Sejalan dengan upaya pembaruan hukum pidana di Indonesia, adanya berbagai kekurangan dan kelemahan sistem pemidanaan anak perlu dilakukan reformulasi, sehingga sejalan dengan esensi peradilan anak yaitu memberikan perlindungan dan kesejahteraan terbaik bagi anak.

Berpijak pada teori hukum pidana yang berorientasi kepada adanya pemisahan antara criminal act dan criminal responsibility, maka kebijakan sistem pemidanaan terhadap anak berorientasi pula pada 3 persoalan pokok, yaitu masalah perbuatan (criminal act/daad), kesalahan (schuld/dader), serta pidana (punish/straft). Masalah yang sangat substansial dalam melakukan kebijakan formulasi sistem pemidanaan anak meliputi:

\section{Tempat Pengaturan}

Sejalan dengan perkembangan pembaruan hukum pidana anak, ketentuan sistem pemidanaan terhadap anak diatur di luar KUHP sebagaimana dengan dikeluarkannya Undang-Undang Nomor 3 Tahun 1997 tentang Pengadilan Anak. Namun demikian kebijakan pembaruan tersebut dirasakan kurang cermat serta tidak didasarkan atas pemikiran yang komprehensif, sehingga tidak atau kurang memperhatikan aspek sinkronisasi dan harmonisasi hukum. Dengan demikian, secara analisis akademis munculnya undang-undang Pengadilan Anak justru menimbulkan persoalan baru.

Melihat dari pengalaman sebagaimana dikembangkan di beberapa negara, kebijakan pengaturan sistem pemidanaan secara umum diatur dan disatukan dalam satu KUHP. Walaupun diatur dalam satu KUHP, pengaturan sistem pemidanaan untuk orang dewasa dipisahkan dan dibedakan dengan sistem pemidanaan bagi anak di bawah umur.

\section{Batas Usia Pertanggungjawaban}

Dalam Undang-Undang No. 3 Tahun 1997 tentang Pengadilan Anak, pengaturan masalah batas usia pertanggunjawaban pidana dirasakan masih terlalu rendah sehingga 
anak usia di bawah 8 tahun masih dimungkinkan untuk diajukan ke sidang anak. Walaupun batas usia tersebut dalam toleransi yang disepakati SMR-JJ Beijing Rule, namun dengan berbagai pertimbangan, bagi masyarakat Indonesia sangat penting untuk menentukan menjadi batas usia yang lebih tinggi dari yang ditetapkan saat ini, yaitu minimum usia 12 tahun. Walaupun masih muncul pendapat bahwa usia 12 dapat dikatakan matang secara fisik, namun secara psikologis belum sepenuhnya.

\section{Kualifikasi Kenakalan Anak}

Masalah penentuan kualifikasi kenakalan anak dalam UU No. 3 Tahun 1997 dirasakan terlalu luas, sehingga perlu dirumuskan kembali dengan mempertimbangkan segala aspek, terutama aspek sosial dan psikologis. Memperhatikan pembedaan antara kenakalan semu yang lingkup kenakalannya masih dalam toleransi nilai-nilai moral, dengan kenakalan nyata yang dinilai melanggar nilai-nilai moral, yang dapat merugikan dirinya maupun masyarakat. Selain itu kajian-kajian kriminologis tentang faktor-faktor causa dari kenakalan anak dapat dijadikan dasar pertimbangan dalam merumuskan lingkup kenakalan anak.

\section{Tujuan dan Pedoman Pemidanaan}

Dalam hal pertanggungjawaban pidana tidak lagi berorientasi kepada perbuatan, sehingga sanksi bukan tujuan, melainkan sarana untuk mencapai tujuan. Oleh karena itu dalam sistem pemidanaan anak masalah tujuan dan pedoman pemidanaan, sangat penting diatur secara tegas. Hal itu sejalan dengan kesepakatan internasional sebagaimana diatur dalam SMR-JJ (Beijing Rule), bahwa sanksi terhadap anak sedapat mungkin menghindarkan tindakan-tindakan yang dapat merampas kemerdekaan. Kalaupun terpaksa harus memenjarakan anak, maka harus dibuat lembaga penjara yang betul-betul menjamin perlindungan dan masa depan anak.

Pemidanaan terhadap anak harus ditujukan untuk :1) mencegah perilaku anak yang lebih buruk dikemudian hari, sehingga menjadi manusia yang baik dan berguna; 2) memberikan perawatan dan perlindungan untuk keselamatan, kesejahteraan dan kesehatan bagi anak; 3) membebaskan rasa bersalah serta menghapuskan stigma buruk pada anak; 4) menciptakan kondisi lingkungan yang baik bagi tumbuh kembangnnya jiwa anak, untuk meningkatkan taraf hidup yang baik bagi pengembangan fisik, mental dan sosialnya.

Berpijak pada tujuan pemidanaan demikian, maka sebagai pedoman hakim sebelum menjatuhkan sanksi, wajib memertimbangkan hal-hal sebagai berikut: 1) 
kesalahan anak yang melakukan kenakalan; 2) motif dan tujuan kenakalan anak; 3) sikap batin kenakalan anak; 4) apakah kenakalan dilakukan dengan sengaja; 5) bagaimana cara melakukan kenakalan; 6) sikap dan tindakan sesudah melakukan kenakalan; 7) riwayat hidup dan keadaan sosial dan ekonomi anak; 8) pengaruh pemberian sanksi terhadap masa depan anak; 9) pengaruh kenakalan anak terhadap korban atau keluarga korban; 10) pemaafan dari korban dan/atau keluarganya; 11) pandangan masyarakat terhadap kenakalan yang dilakukan; 12) ringannya perbuatan, keadaan pribadi pembuat, atau keadaan pada waktu dilakukan perbuatan atau yang terjadi kemudian, dapat dijadikan dasar pertimbangan untuk tidak menjatuhkan sanksi dengan memertimbangkan segi keadilan dan kemanusiaan.

\section{Perumusan Sanksi}

Beranjak dari konsepsi peradilan dilaksanakan untuk memberikan perlindungan demi mencapai kesejahteraan anak, maka dalam perumusan sanksi perlu didasarkan kepada konsepsi ide rehabilitasi, resosialisasi, serta individualisasi pidana.

Dalam perumusan sanksi dipakai perumusan tunggal serta alternatif. Namun untuk menghindari sifat kaku dan absolut dari perumusan tunggal, maka ditegaskan pedoman bagi hakim, bahwa: a) kewenangan hakim untuk tidak menjatuhkan pidana penjara yang dirumuskan secara tunggal; b) keadaan-keadaan atau syaratsyarat untuk dapat tidak menjatuhkan pidana penjara; c) jenis alternatif sanksi yang dapat dijatuhkan oleh hakim sebagai pengganti dari pidana penjara yang tidak dijatuhkan itu. Sedangkan dalam perumusan alternatif ditujukan dalam rangka memberikan kerangka kebijakan untuk menerapkan prinsip subsidiaritas penggunaan sanksi.

\section{Jenis Sanksi}

Sejalan konsep peradilan restorative dengan filosofi keadilan dalam sistem pemidanaan, maka jenis sanksi bagi anak harus sejalan dengan kepada tujuan dan pedoman pemidanaan bagi anak. Oleh karena itu, dengan memperhatikan karekteristik perilaku kenakalan, karekteristik anak, serta mengedepankan tujuan pedagogi, masa depan anak merupakan faktor yang paling dominan dalam penentuan jenis sanksi.

Memperhatikan SMR-JJ (Beijing Rules) bahwa bentuk- bentuk penempatan anak antara lain: a) untuk memperoleh asuhan, bimbingan dan pengawasan; $b$ ) probation; 
c) kerja sosial; d) sanksi pinansial, kompensasi dan ganti rugi; e) pembinaan; f) berperanserta untuk kelompok konseling dan kegiatan yang serupa; g) berhubungan dengan hal-hal bantuan pengasuhan, hidup bermasyarakat dan pembinaan pendidikan lain; serta $\mathrm{h}$ ) hal-hal yang relevan lainnya.

Perumusan jenis sanksi bagi anak meliputi: 1 pidana pokok yang terdiri atas: a) pidana verbal : 1) pidana peringatan; atau 2) pidana teguran keras; b) Pidana dengan syarat: 1) pidana pembinaan di luar lembaga; 2) pidana kerja sosial; atau 3) pidana pengawasan; c) Pidana denda; atau d) Pidana pembatasan kebebasan: 1) pidana pembinaan di dalam lembaga; 2) pidana penjara; atau 3) pidana tutupan. 2. pidana tambahan terdiri atas: a) perampasan barang-barang tertentu dan/atau tagihan; b) pembayaran ganti kerugian; atau c) pemenuhan kewajiban adat.

Tindakan yang dapat dijatuhkan terhadap anak, dapat berupa: 1. perawatan di rumah sakit jiwa; 2. penyerahan kepada pemerintah; atau 3. penyerahan kepada seseorang. Tindakan yang dapat dikenakan terhadap anak tanpa menjatuhkan pidana pokok, meliputi: 1. pengembalian kepada orang tua, wali, atau pengasuhnya; 2. penyerahan kepada Pemerintah; 3. penyerahan kepada seseorang; 4. keharusan mengikuti suatu latihan yang diadakan oleh pemerintah atau badan swasta; 5 . pencabutan surat izin mengemudi; 6 . perampasan keuntungan yang diperoleh dari tindak pidana; 7. perbaikan akibat tindak pidana; 8. rehabilitasi; dan/atau 9. perawatan di lembaga.

\section{Ukuran Pemidanaan}

Dalam hukum pidana positif, pemidanaan terhadap anak lebih berorientasi kepada ukuran kuantitatif, sehingga sanksi didasarkan kepada lama atau pendeknya waktu. Ukuran demikian sangat tidak mencerminkan perlindungan yang baik bagi anak. Oleh karena itu, sejalan dengan upaya perlindungan demi mencapai kesedjahtaraan anak, maka sejauh mungkin menghindarkan sanksi perampasan/ pembatasan kemerdekaan. Namun kalaupun sanksi pembatasan kemerdekaan harus dilakukan, prinsip yang harus diutamakan adalah memberikan perlindungan yang terbaik bagi demi mencapai kesejahteraan anak.

\section{Penutup}

Dari apa yang telah diuraikan dalam pembahasan terdahulu, dapat disimpulkan hal-hal, sebagai berikut: a. kebijakan formulasi sistem pemidanaan anak dalam 
hukum pidana positif baik dalam KUHP maupun Undang-Undang Nomor 3 Tahun 1997 tentang Pengadilan Anak, dilihat dari aspek kebijakan/politik kriminal belum sesuai dengan hakikat dilaksanakannya peradilan anak yaitu memberikan perlindungan hukum dan rehabilitasi anak delinkuen. b. konsep kebijakan formulasi sistem pemidanaan anak yang dapat memberikan perlindungan demi tercapainya kesejahteraan anak, antara lain adanya ngaturan sistem pemidanaan secara utuh dan tidak bersifat parsial. Secara substansial ditetapkan usia 12 tahun sebagai batas usia minimun anak yang dapat diminta pertanggungjawaban pidana, serta adanya perumusan kriteria anak nakal secara jelas dengan berpijak pada prinsip kepastian hukum.

Bertitik tolak dari tujuan memberikan yang terbaik bagi anak, selain diatur secara tegas tujuan dan pedoman pemidanaan bagi anak, ancaman sanksi dirumuskan secara alternatif dengan menghindarkan penerapan sanksi pembatasan kemerdekaan serta memperhatikan pengaruh psikologis dan stigma terhadap masa depan anak.

Atas dasar hasil analisis dan simpulan inti permasalahan dapat diajukan saran, sebagai berikut: a. dalam penyusunan sistem pemidanaan terhadap anak, sebaiknya para pembuat kebijakan mengkaji keseluruhan sistem pemidanaan dengan memperhatikan sinkronisasi dan harmonisasi penyusunan perundang-undangan. b. sejalan dengan program penyusunan Rancangan KUHP, KUHAP, maupun sistem pemasyarakatan sebaiknya proses pembaruan hukum pidana anak dilakukan secara bersamaan. c. dalam penyusunan sistem pemidanaan anak selain memperhatikan nilai-nilai budaya bangsa, perlu juga memperhatikan perkembangan instrumeninstrumen tentang perlindungan anak yang telah disepakati masyarakat internasional. d. untuk menghindari proses stigmatisasi terhadap anak yang bermasalah dengan hukum hendaknya aparat penegak hukum khususnya pihak kepolisian, dalam melakukan tindakan penangkapan maupun penahanan dilakukan secara selektif dengan mempertimbangkan kepentingan anak. e. dalam merumuskan stelsel pemidanaan terhadap anak, sedapat mungkin mencari alternatif sanksi pidana perampasan kemerdekaan dengan prinsip rehabilitasi, reedukasi, resosialisasi, serta prinsip individualisasi pidana. f. perlu dilakukan upaya-upaya peningkatan kesejahteraan keluarga, serta peningkatan pemahaman para orang tua (dalam arti yang luas), tentang hakikat keberadaan anak dalam lingkungannya, serta hak dan kewajibannya masing-masing. 


\section{Daftar Pustaka}

Ancel, Marc, Social Defance, A Modern Approach to Criminal Problems, Routlarge \& Kegan Paul, London, 1965.

Hamzah, Andi, Pembangunan Hukum Pidana Indonesia, makalah Seminar Pengaruh Globalisasi terhadap Hukum Pidana dan Kriminologi Menghadapi Kejahatan Transnasional, ASPEHUPIKI, Bandung, Maret 2008.

Harkrisnowo, Harkristuti, Rekonstruksi Konsep Pemidanaan : Suatu Gugatan terhadap Proses Legislasi dan Pemidanaan di Indonesia, Pidato Pengukuhan Jabatan Guru Besar Tetap dalam Ilmu Hukum Pidana, Fakultas Hukum Universitas Indonesia, Depok, 2003.

L. Packer, Herbert, "The Limit of The Criminal Sanction", Standford University Press, California, 1968.

Muladi, Beberapa Catatan Berkaitan Dengan RUU KUHP Baru, Makalah Seminar Nasional RUU KUHP Nasional, Universitas Internasional Batam, Batam, 2004.

Nawawi Arief, Barda, Beberapa Aspek Pengembangan Ilmu Hukum Pidana (Menyongsong Generasi Baru Hukum Pidana Indonesia). Pidato pengukuhan Penerimaan Jabatan Guru Besar dalam Ilmu Hukum Pada Fakultas Hukum Universitas Diponegoro, Semarang, 1994.

, Kebijakan Legislatif dalam Penanggulangan Kejahatan dengan Pidana Penjara, CV. Ananta, Semarang, 1994.

, Kebijakan Hukum Pidana (Penal Policy), tanpa tahun dan penerbit.

Nazir, Moh., Metode Penelitian, Ghalia Indonesia, Jakarta, 2003.

Soesilo. R., Kitab Undang-Undang Hukum Pidana (KUHP) serta Komentar-Komentarnya Lengkap Pasal Demi Pasal.

Sudarto, Hukum dan Hukum Pidana, Alumni, Bandung, 1981.

Suatu Dilema dalam Pembaharuan Sistem Pidana Indonesia, Fakultas Hukum Universitas Diponegoro, 1979.

Hukum Pidana dan Perkembangan Masyarakat. Kajian terhadap pembaharuan hukum pidana.Sinar Baru, Bandung, 1983.

Kapita Selekta Hukum Pidana, Alumni, Bandung, 1981.

Supranto, J., Metode Penelitian Hukum dan Statistik, Rineka Cipta, Jakarta, 2000.

Zani Arbi, Sutan dan Wayan Ardhana, Rencana Penelitian Kebijakan Sosial, Pustekkom Dikbud dan C.V. Radjawali, Jakarta, 1984.

Deklarasi PBB Universal Declaration of Human Rights tahun 1948. Deklarasi ini mendasari disahkannya Deklarasi Hak-Hak Anak (Declaration on The Rights of The Child) oleh Majelis Umum PBB pada tanggal 20 November 1958.

Moeljatno, Kitab Undang-Undang Hukum Pidana (KUHP). 
Ninth U.N. Congres on The Prevention of Crime and the Treatment of Offenders, Draft Resolution No. A/CON/169/L.5, Kairo, Mesir 29 April-8 Mei 1995.

Rancangan Undang-Undang Republik Indonesia, ELSAM, Jakarta, 2005.

Rancangan Undang-Undang Republik Indonesia. Direktorat Jendral Peraturan Perundang-Undangan Departemen Hukum dan Hak Asasi Manusia, Tahun 2007.

Resolusi PBB Nomor. 44/25, 20 November 1989.

Undang-Undang Nomor 12 Tahun 1995 tentang Pemasyarakatan.

Undang-Undang Dasar Republik Indonesia 1945, Amandemen kedua.

Undang-Undang Nomor 3 Tahun 1997 tentang Pengadilan Anak, Lembaran Negara Republik Indonesia tahun 1997.

Undang-Undang Dasar Republik Indonesia 1945, Amandemen kedua.

Undang-Undang Nomor 4 Tahun 1979 tentang Kesejahteran Anak. Lembaran Negara RI Tahun 1979 No. 32.

Undang-Undang Nomor 8 Tahun 1981 tentang Kitab Undang-Undang Hukum Acara Pidana (KUHP).

United Nations, Standard Minimum Rules For The Administration Of Juvenile Justice (Beijing Rules), Departement of Public Information, New York, 1986.

Undang-Undang Nomor 39 Tahun 1999 tentang HAM. Jakarta,Sinar Grafika, 2001.

Undang-Undang Nomor 23 Tahun 2002 tentang Perlindungan Anak. Lembaran Negara Republik Indonesia No. 4235.

Undang-Undang Nomor 48 Tahun 2009 tentang Kekuasaan Kehakiman. 